\title{
Proceeding
}

Supplementary Issue: Summer Conferences of Sports Science. Costa Blanca Sports Science Events, 25-26 September 2020. Alicante, Spain.

\section{Motivation and self-efficacy influence in the academic performance of Secondary students-athletes}

\author{
FRANCISCO TOMÁS GONZÁLEZ-FERNÁNDEZ1 ${ }^{1}$, SALVADOR BAENA-MORALES² \, DANIEL RAMOS- \\ PÉREZ3 ${ }^{3}$ HONORATO MORENTE-ORIA ${ }^{3}$ \\ ${ }^{1}$ Department of Physical Activity and Sports Sciences, Pontifical University of Comillas, Mallorca, Spain \\ ${ }^{2}$ Faculty of Education, University of Alicante, Spain \\ ${ }^{3}$ Didactic of Languages, Arts and Sport's Department, University of Malaga, Spain
}

\begin{abstract}
The present study investigated the relationship between Academic Performance, Goal-orientations, Motivation, self-efficacy and Academic satisfaction. Seventy-four healthy secondary school students-athletes participated in the present research. The results showed correlations between the different variables analysed. Thus, we found a positive correlation between self-efficacy and qualifications, and task-goals with achievements-motive. However, the avoidance of negative judgments correlates negatively with task-goals and positively with inhibitor anxiety. Comparative analysis showed that were no differences according to gender, although significant differences were depending on the level of academic, mainly in ego-goals. Finally, another comparative analysis using the scores an independent variable, showed that students with higher grades presented more orientation to the goals-task and greater self-efficacy. The present study demonstrates a positive correlation between self-efficacy and ratings or score, task-goals, and achievementsmotive. Thus, we can suggest an individualized study of each child where self-efficacy could be seen as a means of predicting new results.

Keywords: Motivation; Academic performance; Self-efficacy.

Cite this article as:

González-Fernández, F.T., Baena-Morales, S., Ramos-Pérez, D., \& Morente-Oria, H. (2020). Motivation and selfefficacy influence in the academic performance of Secondary students-athletes. Journal of Human Sport and Exercise, 15(4proc), S1059-S1070. doi:https://doi.org/10.14198/jhse.2020.15.Proc4.08

Corresponding author. Faculty of Education, University of Alicante, Calle Aeroplano s/n 03690 San Vicente del Raspeig (Alicante). Spain. https://orcid.org/0000-0002-6722-3714

E-mail: salvador.baena@ua.es

Abstract submitted to: Spring Conferences of Sports Science. Costa Blanca Sports Science Events, 19-20 June 2020. Alicante, Spain. Communication highlighted as "Best Communication Award".

JOURNAL OF HUMAN SPORT \& EXERCISE ISSN 1988-5202

(c) Faculty of Education. University of Alicante

doi:10.14198/jhse.2020.15.Proc4.08
\end{abstract}

VOLUME 15 | Proc4 | 2020 | S1059 


\section{INTRODUCTION}

Teachers, educators, pedagogues, and educational psychologists consider different variables or factors (environmental or personal) that could be manipulated with the intention of improvements in academic accomplishment (Academic Performance-AP) e.g., student predisposition (Sepúlveda et al., 2009). Other essential factors to be considered are that the student, depending on the course level, change their goal, identify different motivational profiles, and its relationship with the Academic Performance could vary (Rodríguez Rodríguez \& Guzmán Rosquete, 2018). Also literature support that the AP is improved by doing Physical Activity as it Physical Fitness develop (Gil Espinosa, Chillón, Morente-Oria, Romance-García, \& Cadenas-Sanchez, 2019; Morales, Millan González, Guerra, Virgili, \& Unnithan, 2011).

In recent years, advances in neuroscience have showed the relationship between AP and academic performance (Mura et al., 2015). Most research details how these improvements are the result of variation in brain structure and function (Donelly et al., 2016). For example, several systematic reviews and metaanalyses compile the effectiveness of performing AP routines with improved academic performance (Donelly et al., 2016; de Greef et al., 2018; Mura et al., 2015; Watson et al., 2016). This improvement in academic performance could be explained by two main factors. On the one hand, the enhancement of psychological variables such as anxiety, self-esteem and mental health (Biddle \& Asare, 2011). On the other hand, by the improvement of cognitive variables such as planning ability (Chan et al., 2012; Nanda, Balde \& Manjunatha, 2013), attention functions (De Bruin, van del Zwan, \& Bogels., 2016) or working memory (Hawkes, Manselle \& Woollacott, 2014), among others.

This cognitive development has a direct implication in the performance of academic tasks. For example, improvement in working memory has been correlated with greater competence in mathematics, reading, or science performance of adolescents (Clair-Thompson \& Gathercole, 2006; Gathercole et al., 2004). Donlley et al. (2016) highlight another example of the relationship between AP and academic performance, as the performance of academic assessment seems to benefit from the decision making skills involved in sport.

However, the performance of physical activity on a routine basis is influenced by internal and external variables that condition increased practice by adolescents. Franco et al., (2020), highlight three main theories to explain the greater or lesser realization of PA the theory of achievement goal, the theory of selfdetermination and the theory of flow.

As commented, Motivation at it different profiles as one of the most important and most studied variables associated to the Teaching-Learning (T-L) process (Franco et al., 2019; Papaioannou et al., 2019) (González-Pienda et al., 2002) and hence one of the subjects of this study. This topic is not only been studied in secondary (Rodríguez Rodríguez \& Guzmán Rosquete, 2018), as this paper, also been studied in High Education level (Camacho-Miñano \& Del Campo, 2015; García Rodríguez \& Álvarez Álvarez, 2007) and primary education (Chen, 2019) arguing student motivations problems at any level and in different parts of the world (Federmeier, 2019).

Academic Performance is also worldwide studied because of its relationship with future performance, and Spanish culture is studied as an indicator for this AP using Spanish Language and Mathematic (Cerda Etchepare \& Vera Sagredo, 2019; Morales \& Galindo, 2002; Rodríguez Rodríguez \& Guzmán Rosquete, 2018). Related to this Research in recent years has shown that the greatest influence factors that have on the subject of mathematics are: 1) the expectations of the parents, 2) the socioeconomic status, 3) the initial 
stimulation, 4) the school context, 5) the teacher's expectations and 6) the teacher's academic degree, among others (Merino \& Álvarez Maldonado, 2014; Valenzuela et al., 2009).

However, if we focus on the theories that can help us explain this interesting problem, the most popular and important theory in the study of academic motivation is the Goal Orientation Theory (Patrick et al., 2001). For this and through this vital theory, we try to find an explanation about student behaviour in academic achievement and also in learning-performance in the school environment (Schunk et al., 2008). In fact, the classifications of these Goal Orientation Theory are well known, among which we can highlight the following: learning goals and performance goals (Elliott \& Dweck, 1988), task goals (Maehr \& Midgley, 1991) mastery goals and execution or performance goals (Ames, 1992; Elliott \& Dweck, 1988) academic goals and social goals (de la Fuente Árias, 2002) and finally, in task-centred goals and self-centred goals called ego goals (Nicholls, 1984).In these last two, it will be the one we will focus on in this final Degree work.

In this paper, we will focus on Task and Ego Goals. Taking into account the former, we can suggest that the main objective seeks to improve or increase competition in what is being done. These types of goals are usually associated with higher levels of effectiveness, task value, interest, positive affect, persistence, and greater use of cognitive and metacognitive strategies (Pintrich, 2000; Wolters, 2004). Ego goals aim to prove being the best, and in the evaluation of itself execution depends on the comparison with others (Navas Martínez et al., 2007). That is why it is linked that the acquisition of the last type of goals has adverse effects on academic performance (Valle et al., 2006).

Following the Goal Orientation Theory and closely linked to them, another relevant aspect is the investigation of anxiety-inhibitory. This characteristic will be fundamental in our work since high levels of this factor will significantly influence the academic performance of the students. In this way, we want to differentiate the results that we can find in the literature according to the specificity of goal theory. Thus, if we choose the theory of execution goals, we will be able to observe high levels of anxiety, lower values of cognitive involvement and persistence in the tasks, as well as low levels in academic performance (Linnenbrink, 2005). On the contrary, the theory of learning goals showed high levels of cognitive involvement, greater values in an effort, and persistence in tasks, besides higher levels in academic performance (Alemán et al., 2011).

In this same sense, we also highlight the motivation to avoid negative judgments. Therefore, if it is observed how students pursue performance-oriented goals, it is likely that aspects that link their behaviour to the demonstration of their ability appear, thus positive relationships between student motivation and self-concern are observed. It was worth (Covington, 2000; Maehr \& Midgley, 1996; Schunk \& Zimmerman, 1994) and negative between them and the desire for learning (Dweck, 1986).

According to Bandura's cognitive-social theory (1982), students' judgments about their ability to perform academic tasks, coupled with their beliefs of self-efficacy, could predict their ability to perform those tasks efficiently as the achievement in different subject (Kan \& Akbaş, 2006). Thus, in obedience to Pajares' studies (2002), we can affirm that self-efficacy, in general, will allow students to face a specific problem, persist in the activity, and develop it successfully. Thus, in the present paper, self-efficacy will be a variable of maximum importance due to the relevance that has been given by current scientific studies (Pajares \& Miller, 1994; Zimmerman et al., 1992).

Also, It has been shown that students with higher self-efficacy show greater precision in their mathematical calculations, and their learning is more persistent than students with low self-efficacy (Pajares \& Valiante, 1999). 
Therefore, most researchers who investigate this important research topic, consider self-efficacy as a predictor of academic performance; therefore, they highlight its importance and its approach in the educational field. In this sense, current studies have shown that self-efficacy differs in its results for reasons related to ethnic / race differences (Academies, 2015) and gender. Pajares (2002) has suggested that the perception of competence and academic achievement is directly related to motivational structures and that these could be linked differently between student environments and socioeconomic levels. Regarding the relationships between gender and self-efficacy, researchers report that male students tend to be safer than students in math, science, and technology (Lent et al., 1991; Pajares \& Miller, 1994). Although, fortunately, differences in academic achievement in these areas are diminishing (Eisenberg et al., 1996).

\section{Objectives and Hypotheses}

The objective of this work is to amplify existing findings concerning the influence of motivation in AP. First, we seek to find out whether motivation beliefs vary by gender; secondly, we look for determining whether self-efficacy has any correlation with AP or motivation and if these are Goal or Task orientation.

\section{METHODS}

\section{Participants}

Seventy-four healthy participants ( 39 males and 35 females) and students at the secondary school participate in the present study. The age of participants was around 12 to 17 years old [First cycle (n: 41; age $=12.63 \pm$ 1.29 ) and second cycle ( $\mathrm{n}: 33$; age $=15.33 \pm 2.23)$ ] All participants completed a previous questionnaire about general characteristics (age, course, and gender). Besides, parents and supervising tutors were carefully informed of the experimental procedures and possible risks and benefits associated with participation in the study. They were then invited to sign an informed consent document before any of the tests were performed. The study was conducted following the Declaration of Helsinki.

\section{Instruments}

Questionnaires, scales and instruments were passed in counterbalanced order to avoid learning and order effects.

Motivation to learning questionnaire (MAPE)

It is a Spanish questionnaire consisting of 80 items with four Likert-scale response options (strongly agree, disagree, agree, strongly agree) elaborated by Alonso Tapia and Sánchez Ferrer (1992) for subjects aged 11-15 years old, with the fundamental objective of enabling the identification of basic motivational patterns related to learning and academic achievement. The questionnaire consists of 8 factors of which, in our study, we have used three and have an internal consistency between .71 and .78; the first two related to the tendency to avoid failure and the third most related to the tendency to success:

Factor 1: Performance inhibitory anxiety: it consists of eleven items. They refer to the nervousness of the subject in evaluation situations.

Factor 2: Prevention of negative judgments of competition: it consists fourteen items. All items are created to evaluate the prevention of negative judgments about the competition itself.

Factor 3: Motivation of showcasing: it consists of thirteen items that refer to the search for a positive evaluation by others and, in some cases, to the avoidance of negative evaluation by others.

General Self-Efficacy Scale

It has been adapted to the Spanish population for Sanjuán, Pérez, and Bermúdez (2000). 
General self-efficacy is a global construct that refers to people's firm belief about their ability to properly handle a wide range of stressors in everyday life. In the different studies carried out with samples of different nationalities, the scale has shown considerable internal consistency (between 0.79 and 0.93 ). In Sanjuán, Pérez, and Bermúdez's study (2000), the scale was applied to a sample of 259 Spanish university students, obtaining an internal consistency of 0.87 and a correlation between two halves of 0.88 .

\section{Task and Ego Orientation in Sports Questionnaire (TEOSQ)}

Spanish version by Balaguer, Castillo, \& Tomás (1996) in which the type of goals towards the student's task or ego is evaluated through 13 items, 7 of which talk about mastery goals and the other 6 of ego goals. The correlation between both factors is 0.03 , demonstrating the independence between them, and their Cronbach coefficients are 0.78 (alpha of the task factor) and 0.80 (alpha of the ego factor), both being adequately consistent.

\section{Academic Performance}

It was assessed through the students' marks average in subjects in the first two evaluations of the course.

\section{Procedure}

The participants were evaluated for five weeks (between April to May). First group of students performed the questionnaires during the first week, the second group of participants conducted the questionnaires, and in the third week and the last week, the rest of the students performed the questionnaires. They were always evaluated at the same time of day. Participants were evaluated once a week (four times in total) to ensure that counterbalancing was effective.

First, the interview was conducted with an academic director and counsellors of secondary school in order to present the mains of the research, describe the evaluation instrument, request permission, and promote their collaboration. Self-reports were answered collectively, voluntarily, and anonymously in the classroom, previously assigning an identification number to answer sheets given to each subject at 10:00 a.m., which were subsequently corrected. Participants were asked to fill the identification data (gender, age, and course), and instructions were read aloud, emphasizing in not leaving answers unanswered. Researchers remained in the classroom during the application of the test in order to resolve doubts and verify the correct completion of answers and identification data. The order of presentation of the test was established randomly for each group of students.

\section{Datal analysis}

Descriptive statistics were represented as mean (SD). Tests of normal distribution and homogeneity (Kolmogorov-Smirnov and Levene's) were conducted on all data before analysis. The results of this task confirmed that data adjusted to typical values. Consequently, Pearson's correlation analysis was performed to observe the direct relationship between different variables (Scores: s; Ego-goals: EG; Task-goals: TG; Anxiety-inhibitory: Al; Avoidance-negative-judgments: ANJ; Reason-achieve: RA; Self-efficacy: SE). Additionally, a t-test was used to compared gender differences, cycles, and scores. The level of significance was $p<.05$. Data analysis was performed using Statistical (version 10 by Statsoft).

\section{RESULTS}

The results obtained by all participants are shown below $(n=74)$. We can see in table 1 , the minimum, maximum scores of students. Also, we can observe the means and standard deviations for each variable (see Table 1). 
Table 1. Descriptive information of all participants (means $\pm \mathrm{SD}$ ).

\begin{tabular}{llll}
\hline & Minimum & Maximum & Means \pm SD \\
\hline S & 2.00 & 10.00 & $5.68 \pm 1.83$ \\
EG & 6.00 & 24.00 & $13.80 \pm 3.89$ \\
TG & 6.00 & 24.00 & $18.82 \pm 3.25$ \\
AI & 13.00 & 36.00 & $25.04 \pm 5.47$ \\
ANJ & 14.00 & 36.00 & $24.07 \pm 4.97$ \\
RA & 16.00 & 46.00 & $30.76 \pm 6.13$ \\
SE & 13.00 & 47.00 & $33.42 \pm 6.62$ \\
\hline
\end{tabular}

Scores: S; Ego-goals: EG; Task-goals: TG; Anxiety-inhibitory: Al; Avoidance-negative-judgments: ANJ; Reason-achieve: RA; Selfefficacy: SE.

Subsequently, looking for relationships between different variables analysed in the present study, we performed a correlation analysis to observe this link between them. For this, we use Pearson's correlation coefficient (See Table 2 for more information).

Table 2. Correlation between each variable of the present study.

\begin{tabular}{llllllll}
\hline & S & EG & TG & Al & ANJ & RA & SE \\
\hline S & 74 & & & & & & \\
EG & -0.090 & 74 & & & & & \\
TG & $0.313^{* *}$ & 0.128 & 74 & & & & \\
Al & -0.110 & 0.181 & 0.147 & 74 & & & \\
ANJ & -0.153 & 0.061 & $-0.256^{*}$ & $0.241^{*}$ & 74 & & \\
RA & 0.039 & $0.477^{* *}$ & $0.375^{* *}$ & 0.133 & -0.016 & 74 & \\
SE & $0.300^{* *}$ & 0.205 & $0.484^{* *}$ & -0.119 & -0.197 & $0.383^{* *}$ & 74
\end{tabular}

Scores: S; Ego-goals: EG; Task-goals: TG; Anxiety-inhibitory: Al; Avoidance-negative-judgments: ANJ; Reason-achieve: RA; Selfefficacy: SE. ${ }^{* *}$ Significant correlation to level .01 (bilateral) * Significant correlation to level .05 (bilateral).

Besides, we performed students' t-test to compared means in the function of gender (see Table 3), cycle (see Table 4), and scores (see Table 5).

Table 3. Means comparations in the function of gender (means \pm SD).

\begin{tabular}{lllll}
\hline & Males & Females & & \\
\hline & Means \pm SD & Means \pm SD & T (72) & $\mathbf{p}$ \\
\hline S & $5.80 \pm 1.91$ & $5.54 \pm 1.75$ & 0.59 & .56 \\
EG & $13.62 \pm 4.12$ & $14.00 \pm 3.66$ & -0.42 & .67 \\
TG & $18.67 \pm 3.28$ & $19.00 \pm 3.25$ & -0.44 & .66 \\
Al & $24.49 \pm 4.70$ & $25.66 \pm 6.23$ & -0.92 & .36 \\
ANJ & $23.95 \pm 4.73$ & $24.20 \pm 5.30$ & -0.22 & .83 \\
RA & $31.23 \pm 6.80$ & $30.23 \pm 5.32$ & 0.70 & .49 \\
SE & $33.64 \pm 7.42$ & $33.17 \pm 5.70$ & 0.30 & .76
\end{tabular}

Scores: s; Ego-goals: EG; Task-goals: TG; Anxiety-inhibitory: Al; Avoidance-negative-judgments: ANJ; Reason-achieve: RA; Selfefficacy: SE. 
After observing the results obtained, we can observe that there were no significant differences according to gender. As can be seen in the means and standard deviation of the table, the results were very similar and were far from statistical significance.

Table 4. Means comparison in the function of a cycle (means \pm SD).

\begin{tabular}{lllll}
\hline & First cycle & Second cycle & & \\
\hline & Means \pm SD & Means \pm SD & T (72) & p \\
\hline S & $5.73 \pm 1.83$ & $5.60 \pm 1.85$ & 0.29 & .77 \\
EG & $12.68 \pm 3.31$ & $15.18 \pm 4.15$ & -2.88 & .05 \\
TG & $18.46 \pm 3.64$ & $19.27 \pm 2.67$ & -1.07 & .29 \\
Al & $23.98 \pm 5.30$ & $26.36 \pm 5.46$ & -1.90 & .06 \\
ANJ & $23.71 \pm 4.78$ & $24.52 \pm 5.24$ & -0.69 & .49 \\
RA & $30.39 \pm 6.50$ & $31.21 \pm 5.69$ & 0.57 & .57 \\
SE & $33.39 \pm 7.16$ & $33.45 \pm 5.99$ & -0.04 & .96
\end{tabular}

Scores: s; Ego-goals: EG; Task-goals: TG; Anxiety-inhibitory: Al; Avoidance-negative-judgments: ANJ; Reason-achieve: RA; Selfefficacy: SE.

The means comparison according of cycle revealed significant differences $E G$ ( $p=.05 ; 12.68 \pm 3.31$ vs. $15.18 \pm 4.15)$ and marginal effects, very near of statistical signification, in $\mathrm{Al}(\mathrm{p}=.06 ; 23.98 \pm 5.30 ; 26.36 \pm$ 5.46), means being higher in second cycle students.

Table 5. Means comparison in the function of scores (means \pm SD).

\begin{tabular}{lllll}
\hline & Low performance & Higher performance & & \\
\hline & Media \pm DT & Media \pm DT & T (47) & p \\
\hline S & $13.70 \pm 5.10$ & $13.15 \pm 3.71$ & 0.43 & .67 \\
EG & $17.87 \pm 4.01$ & $20.12 \pm 2.41$ & -2.41 & .02 \\
TG & $26.35 \pm 6.49$ & $23.65 \pm 5.03$ & 1.63 & .11 \\
AN J & $24.83 \pm 5.17$ & $22.92 \pm 5.48$ & 1.24 & .22 \\
RA & $30.39 \pm 6.51$ & $30.80 \pm 6.68$ & -0.22 & .83 \\
SE & $31.13 \pm 9.05$ & $35.54 \pm 5.61$ & -2.08 & .04 \\
\hline
\end{tabular}

Scores: S; Ego-goals: EG; Task-goals: TG; Anxiety-inhibitory: Al; Avoidance-negative-judgments: ANJ; Reason-achieve: RA; Selfefficacy: $S E$.

First, we have to comment about the elaboration of two groups (low performance and high performance and low performance), that we compare. Thus, from means $+/$ - standard deviation (means $=5.67 ; 1 / 2 S x=0.91$ ), we obtain two groups with extreme scores. Low-performance group $(n=23)$ with scores lower to 4 points and higher performance group $(n=26$ ) with scores higher to 7 points. Means comparison using scores like independent variable, showed that student with higher scores presented more orientation to TG ( $p=.02$; $17.87 \pm 4.01$ vs. $20.12 \pm 2.41)$ and higher $S E(p=.04 ; 31.13 \pm 9.05$ vs. $35.54 \pm 5.61)$.

\section{DISCUSSION AND CONCLUSION}

The aim of this study was to evaluate the AP and it relationship between performance, goal-orientations, motivation, and academic satisfaction. In order to achieve our objective, seventy-four healthy participants and students at a secondary school participated and completed different questionnaires to show self-efficacy, academic performance, pattern of school failure and task-goals, and achievements-motive. 
The outcome of the present study showed correlations between the different variables analysed. Thus, we found a positive correlation between and ratings or score and task goals and other correlation between the achievements-motive and ego-goals and task goals. On one hand, this latter result is consistent with recent accounts suggesting a better AP in students with confidence in their own abilities (Jaime, Martin, Flores \& Garrido 2011). On the other hand, tendency to avoid failure, to appear in our variables like inhibitory-anxiety and avoidance-negative-judgment, correlate positively between themselves and negatively with goals-task, it implies a logical relationship and explain the better results in self- efficacy. The belief that research about convictions of efficacy showed that have an influence in motivational orientation and in effort and persistent index (Nuñez, 2009). In this sense, Bandura (1982) indicate that students with doubts about his capacity or ability to develop wherever activity may tend to participate in particular task and dedicate less individual effort.

The correlation between ego-goals and self-efficacy showed highly correlated to the first due student pursues high scores. In fact, the last correlation has influence of attributions, reason-achieve and self-efficacy and his relationship with conduct to regular learning routine (Tapia, 2007).

Firstly, ego-goals correlate highly with the motivation of achievement and motivation of showcasing because both are extrinsic. In this sense, is important know that both are looks for avoidance of judgments but also seeks to avoid negative judgments. Although, it has been showed that ego-goals are likely to be divided into two aspects: one of self-protection, coinciding with the traditional approach, an another of self-improvement, not showing off, where the desire to sucked, stand out, be the best is hidden. In comparison with others, without having to affect the feeling of self-concept (Soriano, 2001). Additionally, other explain to these results is that ego-goal correlate also with self-efficacy, motivation due to students pursuing good scores.

Secondly, after observing and valuing all the correlations obtained, we carried out comparative analysis according to the gender, the cycle to which the belonged and the performance obtained in the notes. Thus, our results showed us that there were no significant differences depending on gender. These results go in another direction with respect to studies that affirmed best results of males students in mathematics, science and technology (Lent, Lopez \& Bieschke, 1991; Pajares \& Miller, 1994) and are closer to that do not find differences in academic achievement between men and women (Eisenberg, Martin \& Fabes, 1996). Ultimately, our results obtained in comparison of means according to cycle in which students were revealed significant differences in ego goals. In this sense, we also found marginal effects, very close to statistical significance, in inhibitory anxiety, being highest average in second cycle students.

Finally, our results showed better scores and more orientation to task-goal and high self-efficacy in our students. Therefore, our results claim that are no differences in gender issues but are differences in self efficacy issues.

In sum, the present study demonstrates a positive correlation between self-efficacy and ratings or score, task-goals, and achievements-motive. The correlation between the achievements-motive and ego-goals and task goals. However, the avoidance of negative judgments correlates negatively with task-goals and positively with inhibitor anxiety. Comparative analysis showed that were no differences according to gender, although significant differences were depending on the level of academic, mainly in ego-goals. Finally, another comparative analysis using the scores an independent variable, showed that students with higher grades presented. 
In conclusion, we can suggest an individualized study of each child where self-efficacy could be seen as a means of predicting new results. Another interesting line of study will be to create individualized motivation programs to avoid negative influence on math performance and goal orientations and academic self-efficacy.

The study presents certain methodological limitations which may limits the statistics results, this will be the case for sample size, age and city of participants mainly. Nonetheless, an important limitation is lack of updates in different variable of classic theories, for example.

\section{REFERENCES}

Academies, N. R. C. of the N. (2015). Variaciones en el desarrollo, influencias socioculturales, y dificultades en el aprendizaje de las matemáticas Trabajo. Edma 0-6: Educación Matemática En La Infancia, 3(2014), 1-22.

Alemán, M. J., Trías, D., \& Curione, K. (2011). Goal orientations, academic achievement and gender in college students. Ciencias Psicológicas, 2, 159-166.

Alonso Tapia, J., \& Sánchez Ferrer, J. (1992). El cuestionario MAPE-I: Motivación hacia el aprendizaje. In J. Alonso Tapia (Ed.), Motivar en la adolescencia: Teoría, evaluación e intervención (pp. 53-92). Publicaciones de la Universidad Autónoma.

Ames, C. (1992). Classrooms: Goals, Structures, and Student Motivation. Journal of Educational Psychology. https://doi.org/10.1037/0022-0663.84.3.261

Balaguer, I., Castillo, I., \& Tomás, I. (1996). Análisis de las propiedades psicométricas del Cuestionario de Orientación al Ego y a la Tarea en el Deporte (TEOSQ) en su traducción al castellano. Psicológica: Revista de Metodología y Psicología Experimental, 17(1), 71-82.

Bandura, A. (1982). Self-efficacy mechanism in human agency. American Psychologist. https://doi.org/10.1037/0003-066X.37.2.122

Biddle, S. J. H., \& Asare, M. (2011). Physical activity and mental health in children and adolescents: A review of reviews. British Journal of Sports Medicine, 45(11), 886-895. https://doi.org/10.1136/bjsports-2011-090185

Camacho-Miñano, M. del M., \& Del Campo, C. (2015). Impacto de la motivación intrínseca en el rendimiento académico a través de trabajos voluntarios: Un análisis empírico. Revista Complutense de Educacion, 26(1), 67-80. https://doi.org/10.5209/rev_RCED.2015.v26.n1.42581

Cerda Etchepare, G., \& Vera Sagredo, A. (2019). Rendimiento en matemáticas: Rol de distintas variables cognitivas y emocionales, su efecto diferencial en función del sexo de los estudiantes en contextos vulnerables. Revista Complutense de Educación, 30(2), 331-346. https://doi.org/10.5209/rced.57389

Chang, Y., Ku, P., Tomporowski, P., Chen F. \& Huang, C. (2012). Effects of acute resistance exercise on late-middleage adults' goal planning. Medicine \& Science Sports Exercise, 44(9), 1773- 1779. https://doi.org/10.1249/MSS.0b013e3182574e0b

Chen, Y. C. (2019). Effect of Mobile Augmented Reality on Learning Performance, Motivation, and Math Anxiety in a Math Course. Journal of Educational Computing Research. https://doi.org/10.1177/0735633119854036

Covington, M. V. (2000). Goal Theory, Motivation, and School Achievement: An Integrative Review. Annual Review of Psychology. https://doi.org/10.1146/annurev.psych.51.1.171

Clair-Thompson HL, Gathercole SE (2006). Executive functions and achievements in school: Shifting, updating, inhibition, and working memory. Quarterly Journal of Experimental Psychology, 59(4):74559. https://doi.org/10.1080/17470210500162854 
De Bruin, E., van del Zwan, J. \& Bogels, S. (2016). A RCT Comparing Daily Mindfulness Meditations, Biofeedback Exercises, and Daily Physical Exercise on Attention Control, Exec-utive Functioning, Mindful Awareness, Self- Compassion, and Worrying in Stressed Young Adults. Mindfulness, 7(5), 1182- 1192. https://doi.org/10.1007/s12671-016-0561-5

de Greeff, J. W., Bosker, R. J., Oosterlaan, J., Visscher, C., \& Hartman, E. (2018). Effects of physical activity on executive functions, attention and academic performance in preado-lescent children: a meta-analysis. Journal of science and medicine in sport, 21(5), 501-507. https://doi.org/10.1016/j.jsams.2017.09.595

de la Fuente Árias, J. (2002). Perspectivas recientes en el estudio de la Motivacion. Escritos de Psicología, 6, 72-84.

Donnelly, J. E., Hillman, C. H., Castelli, D., Etnier, J. L., Lee, S., Tomporowski, P., Lam-bourne, K., \& Szabo-Reed, A. N. (2016). Physical Activity, Fitness, Cognitive Function, and Academic Achievement in Children: A Systematic Review. Medicine and science in sports and exercise, 48(6), 1197-1222. https://doi.org/10.1249/MSS.0000000000000901

Dweck, C. S. (1986). Motivational Processes Affecting Learning. American Psychologist. https://doi.org/10.1037/0003-066X.41.10.1040

Eisenberg, N., Martin, C. L., \& Fabes, R. A. (1996). Gender development and gender effects. In D. C. Berliner \& R. C. Calfee (Eds.), Handbook of education psychology (1st ed., p. 899). Simon \& Schuster Macmillan.

Elliott, E. S., \& Dweck, C. S. (1988). Goals: An Approach to Motivation and Achievement. Journal of Personality and Social Psychology. https://doi.org/10.1037/0022-3514.54.1.5

Federmeier, K. D. (2019). The psychology of learning and motivation. Academic Press. (K. D. Federmeier (ed.); 71st ed.). Academic Press.

Franco, E., Coterón, J., Huéscar, E., \& Moreno-Murcia, J. A. (2019). A Person-Centered Approach in Physical Education to Better Understand Low-Motivation Students. Journal of Teaching in Physical Education, 39(1), 91-101. https://doi.org/10.1123/jtpe.2019-0028

García Rodríguez, N., \& Álvarez Álvarez, B. (2007). La motivación del alumnado a través de la satisfacción con la asignatura: efecto sobre el rendimiento. ESE : Estudios Sobre Educación, 13, 89112.

Gathercole SE, Pickering SJ, Knight C, Stegmann Z. (2004). Working memory skills and edu-cational attainment: evidence from national curriculum assessments at 7 and 14 years of age. Applied Cognitive Psychology. 18(1):1-16. https://doi.org/10.1002/acp.934

Gil Espinosa, F. J., Chillón, P., Morente-Oria, H., Romance-García, Á. R., \& Cadenas-Sanchez, C. (2019). La condición física mejora el rendimiento académico en educación secundaria obligatoria. Brazilian Journal of Development, 5(6), 23511-23521. https://doi.org/10.34117/bjdv5n11-062

González-Pienda, J. A., González Cabanach, R., Pérez Núñez, J. C., \& Valle Arias, A. (2002). Manual de Psicología de la Educación (1a). Pirámide.

Hawkes, T., Manselle, W. \& Woollacott, M. (2014). Cross-Sectional Comparison of Executive Attention Function in Normally Aging Long-Term T'ai Chi, Meditation, and Aerobic Fitness Practitioners Versus Sedentary Adults. Journal of Alternative Complementary Medicine, 20(3), 178-184. https://doi.org/10.1089/acm.2013.0266

Kan, A., \& Akbaş, A. (2006). Affective factors that influence chemistry achievement (attitude and self efficacy) and the power of these factors to predict chemistry achievement-I. Journal of Turkish Science Education, 3(1), 76-85.

Lent, R. W., Lopez, F. G., \& Bieschke, K. J. (1991). Mathematics Self-Efficacy: Sources and Relation to Science-Based Career Choice. Journal of Counseling Psychology, 38(4), 424-430. https://doi.org/10.1037/0022-0167.38.4.424 
Linnenbrink, E. A. (2005). The dilemma of performance-approach goals: The use of multiple goal contexts to promote students' motivation and learning. Journal of Educational Psychology. https://doi.org/10.1037/0022-0663.97.2.197

Maehr, M. L., \& Midgley, C. (1991). Enhancing Student Motivation: A Schoolwide Approach. Educational Psychologist. https://doi.org/10.1080/00461520.1991.9653140

Maehr, M., \& Midgley, C. (1996). Transforming school cultures. In Westview Press.

Merino, J. M., \& Álvarez Maldonado, J. (2014). Estudio de efectos contextuales en el rendimiento en matemáticas de alumnos de $8^{\circ}$ básico de la región del Biobío, Chile. Estudios Pedagogicos, 40(2), 241-263. https://doi.org/10.4067/s0718-07052014000300015

Morales, J., Millan González, L., Guerra, M., Virgili, C., \& Unnithan, V. (2011). Physical activity, perceptual-motor performance. International Journal of Sport Psychology, 42, 401-415.

Morales, L., \& Galindo, C. (2002). Clima Social Familiar (Relaciones, Desarrollo Y Estabilidad).

Mura, G., Vellante, M., Nardi, A. E., Machado, S., \& Carta, M. G. (2015). Effects of School-Based Physical Activity Interventions on Cognition and Academic Achievement: A Systematic Review. CNS \& $\begin{array}{llll}\text { neurological disorders drug 1194-1208. } & \text { 14(9), }\end{array}$ https://doi.org/10.2174/1871527315666151111121536

Nanda, B., Balde, J. \& Manjunatha, S. (2013). The Acute Effects of a Single Bout of Moder-ate-intensity Aerobic Exercise on Cognitive Functions in Healthy Adult Males. Journal of Clinical and Diagnostic Research, 7(9), 1883-1885.

Navas Martínez, L., Iborra Muñiz, G., \& Sampascula Maicas, G. (2007). Las metas académicas de los estudiantes de ESO en la clase de música. Revista de Psicodidáctica, 12(1), 131-142.

Nicholls, J. G. (1984). Achievement motivation: Conceptions of ability, subjective experience, task choice, and performance. Psychological Review. https://doi.org/10.1037/0033-295X.91.3.328

Pajares, F. (2002). Gender and Perceived Self-Efficacy in Self- Regulated Learning. Theory into Practice, 41(2), 116-125. https://doi.org/10.1207/s15430421tip4102_8

Pajares, F., \& Miller, M. D. (1994). Role of Self-Efficacy and Self-Concept Beliefs in Mathematical Problem Solving: A Path Analysis. 86(2), 193-203. https://doi.org/10.1037/0022-0663.86.2.193

Pajares, F., \& Valiante, G. (1999). Grade Level and Gender Differences in the Writing Self-Beliefs of Middle School Students. Contemporary Educational Psychology, 24(4), 390-405. https://doi.org/10.1006/ceps.1998.0995

Papaioannou, A., Milosis, D., \& Gotzaridis, C. (2019). Interdisciplinary Teaching of Physics in Physical Education: Effects on Students' Autonomous Motivation and Satisfaction. Journal of Teaching in Physical Education, 39(2), 156-164. https://doi.org/10.1123/jtpe.2018-0315

Patrick, H., Anderman, L. H., Ryan, A. M., Edelin, K. C., \& Midgley, C. (2001). Teachers' communication of goal orientations in four fifth-grade classrooms. Elementary School Journal. https://doi.org/10.1086/499692

Pintrich, P. R. (2000). Multiple goals, multiple pathways: The role of goal orientation in learning and achievement. Journal of Educational Psychology. https://doi.org/10.1037/0022-0663.92.3.544

Rodríguez Rodríguez, D., \& Guzmán Rosquete, R. (2018). Relación entre perfil motivacional y rendimiento académico en Educación Secundaria Obligatoria. Estudios Sobre Educacion, 34, 199217. https://doi.org/10.15581/004.34.199-217

Sanjuán Suárez, P., Pérez García, A. M., \& Bermúdez Moreno, J. (2000). Escala de autoeficacia general: Datos psicométricos de la adaptación para población española. Psicothema, 12(SUPPL. 2), 509513.

Schunk, D. H., Pintrich, P. R., \& Meece, J. L. (2008). Motivation in education : theory, research, and applications (D. H. Schunk (ed.); 3rd ed.). Prentice Hall. 
Schunk, D., \& Zimmerman, B. (1994). Self-regulation of learning and performance: Issues and educational applications (1st ed.). Lawrence Erlbaum Associates, Inc.

Sepúlveda, A., Medina, C., \& Sepúlveda, D. (2009). La resolución de problemas y el uso de tareas en la enseñanza de las matemáticas. Educación Matemática, 21(2), 79-115.

Valenzuela, J. P., Bellei, C., Sevilla, A., \& Osses, A. (2009). ¿Qué explica las diferencias de resultados PISA Lectura entre Chile y algunos países de la OCDE y América Latina? Unidad de Currriculum y Evaluación, December, 105-148.

Valle, A., Cabanach, R. G., Rodríguez, S., Núñez, J. C., \& González-Pienda, J. A. (2006). Metas académicas, estrategias cognitivas y estrategias de autorregulación del estudio. Psicothema.

Watson, A., Timperio, A., Brown, H., Best, K., \& Hesketh, K. D. (2017). Effect of classroom-based physical activity interventions on academic and physical activity outcomes: a sys-tematic review and meta-analysis. The international journal of behavioral nutrition and physical activity, 14(1), 114. https://doi.org/10.1186/s12966-017-0569-9

Wolters, C. A. (2004). Advancing achievement goal theory: Using goal structures and goal orientations to predict students' motivation, cognition, and achievement. Journal of Educational Psychology. https://doi.org/10.1037/0022-0663.96.2.236

Zimmerman, B. J., Bandura, A., \& Martinez-Pons, M. (1992). Self-Motivation for Academic Attainment: The Role of Self-Efficacy Beliefs and Personal Goal Setting. American Educational Research Journal, 29(3), 663-676. https://doi.org/10.3102/00028312029003663

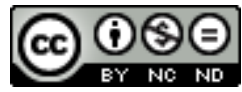

This work is licensed under a Attribution-NonCommercial-NoDerivatives 4.0 International (CC BY-NC-ND 4.0). 